\title{
A EMERGÊNCIA DOS "REMANESCENTES": NOTAS PARA O DIÁLOGO ENTRE INDÍGENAS E QUILOMBOLAS*
}

J osé M aurício Andion Arruti

Articular historicamente o passado não significa conhecê-lo "como ele de fato foi". Significa apropriar-se de uma reminiscência, tal como ela relampeja no momento de um perigo (Walter Benjamin, Sobre o Conceito de História).

Para aqueles que se interessam pela gênese das categorias sociais, ou pela "formação" (no sentido thompsoniano) das classes, estratos ou grupos como "sujeitos políticos", a história do Brasil passa por um momento privilegiado, apesar da apatia, ou justamente por causa dela, que se apoderou da política convencional. Novos sujeitos de interesse entram em cena, não só por conta do crescimento de grupos e potencialização de “lutas" já existentes, como no caso do M ovimento dos Sem-Terra, mas também em função da criação de novas figuras legais, os chamados "direitos insurgentes" (Silva 1994), que penetram nosso direito positivo através dessas rachaduras hermenêuticas que são os "direitos difusos". A partir deles, ganham espaço as "populações tradicionais", particularmente aquelas a que se refere o "Artigo 68", conhecidas, desde então, como "comunidades remanescentes de quilombos" 1. Este texto pretende tomar como objeto de reflexão tais criações sociais, feitas simultaneamente de imaginação sociológica, criações jurídicas, vontade política e desejos.

Depois de ter sido aprovado sem maiores discussões como uma das disposições constitucionais transitórias, não tanto pelo seu valor intrínseco, mas como mais um item no pacote das festividades pelo centenário da abolição da escravatura, o "Artigo 68" ficou sem qualquer proposta de regulamentação² até 1995, quando (então associado às festividades pela memória de Zumbi de Palmares) ganha importância e passa a ser alvo de debates e reflexões em âmbito nacional. Nessas discussões, fundamentalmente orientadas pela necessidade de responder às demandas de natureza jurídica e legislativa, a questão que desponta como central é 
a da própria definição do que foram, historicamente, os quilombos, na expectativa de, a partir daí, poder discernir os critérios de identificação daquelas comunidades "remanescentes".

Ainda que os resultados dessas discussões (e as formas de acesso a elas) estejam surgindo apenas muito lentamente, principalmente em encontros científicos e políticos, as novas contribuições são de grande importância, tanto no plano conceitual, como resultado do debate entre historiadores e antropólogos, quanto normativo, uma vez que existem dois projetos de regulamentação do artigo e duas portarias produzidas pelos órgãos estatais que têm tomado a si a responsabilidade de atuação na área. Essas contribuições, no entanto, são de natureza muito diferentes, já que nelas aparecem, lado a lado, o interesse mais estritamente acadêmico, cujo engajamento com as causas populares é mediado por problemáticas que têm origem em tradições disciplinares e debates conceituais, e o interesse mais diretamente vinculado àquelas lutas, que surge muito freqüentemente associado à causa de uma comunidade, ou de uma região. Neste último caso, com mais evidência que no primeiro, ressurge o desafio de trabalhar simultaneamente com dois universos de referência muito distintos e, por vezes, incompatíveis: o da análise científica e o da intervenção e interpretação jurídica, tema já bastante controverso entre os antropólogos ligados à questão indígena, freqüentemente solicitados a participar como "peritos" em processos judiciais (Silva, Luz e Helm 1994).

Não é por acaso que estamos assistindo a uma considerável translação de "especialistas" (ONG's e antropólogos) de um tema ao outro, lançando mão do instrumental crítico e do acúmulo das técnicas de mediação e intervenção sobre a "terra indígena", para uma atuação sobre as "terras de pretos", ou como insistem nossos legisladores, terras de "comunidades remanescentes de quilombos". Aqui, permitindo-me manter um tom mais livre que rigoroso, explorarei os pontos de encontro entre essas duas temáticas, sugerindo que eles devem ir (suposição e imperativo) muito além da migração de "especialistas", ultrapassando esse aspecto mais ou menos conjuntural para assumir um caráter sistemático e reflexivo, fundamental, do meu ponto de vista, na retomada da história dessas populações e na análise de sua realidade atual.

Para tanto, este artigo não se apóia em uma leitura sistemática da bibliografia existente, mas em um rearranjo dos fragmentos disponíveis e em alguns dados de campo, alterando a ênfase sobre uma questão que não é desconhecida, mas que ocupa um espaço periférico nos trabalhos existentes, procurando tirar partido das relações (materiais, simbólicas e 
analógicas) entre populações indígenas e populações negras, seja enquanto chaves classificatórias, seja enquanto populações históricas submetidas/rebeladas ou enquanto novos sujeitos políticos criadores de cultura.

\section{Raça e etnia: apontamentos sobre uma mitologia savante}

Evitemos os atalhos. Se tomarmos a liberdade de dar ao "pensamento social brasileiro" o estatuto de uma cosmologia nacional, veremos que (apesar do que foi dito sobre a fábula das três raças) ela se organizou, em boa medida, mediante a repartição de grupos humanos em universos semânticos distintos: depois de um primeiro momento de indistinção conceitual, a produção intelectual posterior à década de 30, progressivamente institucionalizada, disciplinada e adaptada às práticas divisórias do discurso acadêmico, passou a dedicar aos indivíduos de ascendência africana a designação de negros, ligando-os à idéia de raça, assim como a dedicar aos de origem americana a designação de índios, ligando-os à idéia de etnia. Poderíamos afirmar que a cada um desses dois recortes da população submetida aos aparel hos e à ideologia do Estado Nacional brasileiro coube uma tradição acadêmica, cada uma com o seu próprio panteão de autores, seu repertório teórico, suas categorias de análise, seus diagnósticos sobre a realidade brasileira. Da mesma forma, o Estado Nacional produziu expedientes de controle cultural e social diferentes para cada um desses recortes, gerando formas distintas de lidar com a alteridade representada por indivíduos não-brancos, incivilizados, inferiores em termos mentais e culturais que, no entanto, precisavam ser assimilados ou absorvidos pela nação brasileira.

Parece ter sido também a premência de responder a esse imperativo de mudança que fez com que aquelas duas tradições de estudos produzissem linhas, trajetórias ideais de transformação, às quais aquelas populações, sob a força de uma vontade sentida como necessidade e pensada como fatalidade, estariam submetidas. Filha da modernidade e orientada pela idéia de progresso, essa mitologia savante, no lugar do tempo cíclico, dispôs dois planos lineares e finitos de sucessivas mutações sócio-étnicoraciais que experimentam forte homologia. Cada uma dessas tradições de estudos, ambas comprometidas em pensar o Estado e moldar o Nacional, produziu, aparentemente de forma autônoma e em seu próprio campo semântico, eixos de mutações estruturalmente semelhantes entre si. Em um deles a diversidade de sociedades e culturas passaria pelas sucessivas reduções representadas pelos termos índio/caboclo/civilizado, enquanto 
no outro, tal redução seria expressa pela sucessão negro/mulato/branco.

A correspondência entre esses termos, no entanto, é de forma e posição, mas não de conteúdo. Substantivamente eles desenham uma perfeita dualidade, que justifica caminharem sobre eixos distintos. Em suas imagens ideais um corresponderia ao isolamento, enquanto o outro à interação, um à pureza enquanto o outro à contaminação. Os atributos da população indígena seriam o exotismo, a alteridade radical, o universo de referências absolutamente estranho que deve ser traduzido, sendo que, neste caso, os dilemas nacionais ficariam por conta da necessidade de integrar, absorver e eliminar, ao mesmo tempo de, sob o signo do romantismo, proteger como núcleo da nacionalidade ou, sob o signo do universalismo, armazenar, junto a tantos outros registros de alteridade, como contribuição a uma visão total do humano. Marcado e valorizado como origem, na sua relação com a "sociedade brasileira" o índio é objeto de contaminação e, neste caso, a alteridade serve à construção de um juízo de valor estético.

Quando a construção desse "nacional" tematiza a população negra, os sinais se invertem: ela representaria para ele o problema da desagradável imagem de si mesmo (um dilema cravado no terreno da identidade e não da alteridade), da necessidade de absorver, integrar, mas sem se contaminar, sem deixar que esse outro, tão íntimo e tão numeroso, altere a imagem de uma nacionalidade ocidentalizante e branca. Neste caso, a universalidade do "problema" não estaria no plano do humano, mas no das populações subalternas que é preciso educar e controlar. Seus dilemas seriam ora os da democracia, ora os do capitalismo, de forma que o sinal positivo recairia não na preservação e no isolamento, mas na mudança e na intervenção. Marcado e desvalorizado como aparência, na sua relação com a "sociedade brasileira" o negro é agente de contaminação, fazendo com que a alteridade sirva, no seu caso, à construção de um juízo de valor político.

As analogias e oposições poderiam avançar através das posições correspondentes daqueles eixos homólogos. Por exemplo, o mulato nos estudos raciais tem um peso e uma positividade que não podem ser comparados com a posição do caboclo nos estudos étnicos ou indigenistas. Este aparece como simples passagem de uma situação à outra, e portanto como uma categoria sociologicamente fraca; enquanto aquele surge como um lugar sempre tematizado, como um vértice quase irredutível. M as também, por outro lado, se "mulato/branco" e "caboclo/civilizado" são os pares finais de uma problematização lançada sobre o tema da população, eles são também o ponto de partida para outro tipo de formulação, 
aquela produzida ou produtora do campo semântico do popular. Transformados em povo, ponto de convergência daqueles eixos, a alteridade domesticada dá ensejo a outras que inicialmente vão ocupar os estudos folclóricos e, depois do expurgo desta perspectiva, os estudos sobre "cultura popular" e "classes populares". O ol har volta-se, então, para um objeto homogêneo e indistinto que, se não apaga, submete toda particularidade (incluindo aí também a diversidade étnica dos imigrantes europeus) que distinguia suas partes entre si e com relação à nação3.

Ainda que esta seja, obviamente, uma forma caricata de nos referirmos aos estudos desses campos (a idéia de cosmologia exclui os debates, os contextos, as subtradições), ela pode ser útil se nosso objetivo for destacar o ponto de deslocamento e a alteração de perspectiva que as novas situações etnográficas nos estão propondo e que têm gerado trabalhos que invertem aqueles modelos. Por um lado, a identificação de comunidades rurais negras que ganham o estatuto de unidades culturais e sociais, por partilharem uma origem e uma cosmologia comuns, uma ancestralidade, por apresentarem grandes índices de endogamia e até mesmo um dialeto particular, escorregando, assim, para o pólo do "isolamento", da alteridade, do exotismo, do universo de referências "autônomo" e original. Por outro, ganham visibilidade política e acadêmica comunidades indígenas "recentes", isto é, que passaram por um processo de retomada de suas tradições a partir de uma identidade genérica de caboclos já assimilados, sem uma língua distinta, cristianizados, muitas vezes integrados aos mercados local e nacional como força de trabalho móvel, escorregando, dessa forma, para o pólo da interação, do universo político e cognitivo partilhado pelo observador.

\section{Índios e negros heterodoxos}

De fato, a observação de situações etnográficas relacionadas a essas duas formas de inversão do padrão dos estudos étnicos e raciais tem levado a uma subversão de posturas e procedimentos canonizados dentro daqueles campos de estudos, heterodoxias que permitem jogar luz sobre grupos sociais antes pensados como irrelevantes ou residuais, mas que, alçados ao estatuto de objetos dignos e pensados em sua positividade, abrem novos campos de análise ao mesmo tempo que têm sua reprodução (e, por vezes, sua produção) social beneficiada ou mesmo garantida por esse seu novo estatuto. A seguir, apresentamos um mapeamento muito sumário do que compreendemos como um movimento convergen- 
te dessas heterodoxias nos campos de estudos étnicos e raciais brasileiros.

No caso do campo de estudos étnicos, nosso ponto de partida é o Nordeste da década de 30, quando alguns pesquisadores inicialmente ligados ao folclorismo, passam a se interessar pelos vestígios de culturas ancestrais em grupos de "remanescentes indígenas", na expressão escoIhida para descrever tais grupos. Motivados pela entrada do Serviço de Proteção ao Índio (SPI) na região e "atraídos" por crescentes demandas daqueles grupos locais (A rruti 1995), esses primeiros acadêmicos ao se dedicarem à temática indígena procuravam naquelas comunidades apenas os traços de suas supostas culturas ancestrais, reconhecendo como digno de nota apenas aqueles elementos que pudessem ajudar na reconstrução de cadeias de famílias lingüísticas, ou na constituição do quadro folclórico regional, com sua ênfase no "sincretismo".

A pesar de terem realizado, durante as décadas de 30 e 40, uma significativa retomada de identidades até então pensadas como extintas, mesmo mais tarde, ao longo das décadas de 60 e 70, tais grupos continuavam sendo pensados como exemplos de processos de assimilação, aculturação e proletarização descaracterizadores, aos quais os grupos indígenas mais cedo ou mais tarde estariam fadados. M esmo sob outras inspirações acadêmicas e referidos a outros quadros teóricos, até muito recentemente os estudiosos permaneceram presos ao diagnóstico básico do iminente desaparecimento, da decadência cultural e da desagregação social.

Foi somente depois de um novo surto de "ressurgimento" de grupos indígenas na região, ao longo das décadas de 70, 80 e 90, e pela conseqüente expansão do campo indigenista fomentado e fomentador dessas emergências étnicas, que a literatura antropológica mudou sua postura diante daqueles grupos. Na década de 90, finalmente, depois de mais de cinqüenta anos de sucessivas emergências e reinvenções, começam a aparecer os primeiros trabalhos que deixam de tematizar a decadência e o desaparecimento dos grupos indígenas do N ordeste para inverter esta perspectiva, abandonando a associação entre a categoria identitária "índios nordestinos" e os modelos de integração e acampesinamento 4 para repensá-la sob os modelos de tradições inventadas (Hobsbawm e Ranger 1984) e etnicidade (Barth 1969). Nesses casos, a abordagem histórica tem assumido grande importância, dando conta das situações de conflito fundiário que envolvem tais grupos, da sua relação com o órgão tutor e da montagem de histórias exemplares, mitos de origem que constantemente são acionados pelos grupos como forma de legitimar suas pretensões, justificar faccionalismos, explicar e fundamentar rituais 5 . 
No caso do campo de estudos raciais, a partir da década de 70 houve uma mudança - talvez a sua própria fundação enquanto "questão" - na abordagem da identidade negra, assumida pelo grupo ou atribuída pelo pesquisador, entre populações eminentemente camponesas. Essa mudança pode ser dividida em dois momentos. No primeiro, que poderíamos pensar como aquele de estudos sobre comunidades rurais que apresentavam a particularidade de serem negras, apareceram como exemplos institucionalmente isolados (Vogt e Fry 1981; 1982; 1983; Vogt, Fry e G nerre 19836; Gusmão 1979; Brandão 1977; Soares 1981; e Telles $\mathrm{s} / \mathrm{d}$ ), não guardando nenhuma perspectiva comum aparente. M as ao Iongo da década de 80, quando tem início na USP uma nova série de estudos interligados e que passam a operar com o conceito de "etnicidade", surgem trabalhos que, invertendo ligeiramente a questão, poderíamos pensar como estudos sobre comunidades negras que tinham a particularidade de serem camponesas. Com isso, até o ano de 1988, haviam sido produzidas duas dissertações de mestrado (Queiroz 1983; M onteiro 1985) e duas teses de doutorado (Baiocchi 1983; Bandeira 1988), enquanto alguns outros trabal hos estavam em andamento7.

Depois do ano de 1988, no entanto, acontecimentos externos aos debates propriamente acadêmicos irão interferir na produção antropológica voltada para os chamados "estudos raciais", no sentido de incentivá-la e de alterá-la. Nesse ano, o “Artigo 68" das disposições transitórias criou a possibilidade de se reconhecer às "comunidades remanescentes de quilombos" o direito sobre as terras que ocupam e, apesar de ainda não se ter Ihe dado uma definição jurídica e institucional, seus efeitos sociais se fizeram sentir quase que imediatamente, pela mobilização de ONG's, aparelhos de Estado, profissionais de justiça e setores da área acadêmica, entre outros, nem sempre, todavia, em perfeito acordo, mesmo quando imbuídos de uma perspectiva política comum. Com isso, o campo de estudos sobre negros passa a ter de responder a novas demandas originadas da luta política, que o levam a uma aliança forçada com perspectivas até então apartadas, impondo aos estudos etnográficos sobre comunidades rurais negras a literatura histórica sobre quilombos e vice-versa.

A bre-se então um novo campo de investimentos, pesquisas são reorientadas e um número crescente de antropólogos, principalmente em período de formação, passa a investir no tema ${ }^{8}$. M as as perspectivas apenas começaram a ser delineadas e o próprio "objeto" encontra-se em fase de definição, criando um espaço analítico ainda amorfo. As poucas bibliotecas que já adotaram o termo "quilombos" como nova chave de entrada em seus fichários, fornecem-nos uma medida da estranheza e da dificul- 
dade em se repensar e reclassificar os antigos estudos sobre comunidades rurais negras em termos de "comunidades remanescentes".

Se a configuração que foi se delineando para os estudos sobre comunidades negras rurais a partir de 1980 já convergia com uma parte dos estudos sobre grupos indígenas (o abandono do culturalismo, marcado pelas noções de "aculturação" e "assimilação", e a adoção de uma abordagem étnica de grupos camponeses), as alterações que Ihes foram impostas a partir das repercussões do "Artigo 68" só vêm aprofundar tal imbricamento. Tais mudanças, como dissemos, tiveram o efeito de impor pela primeira vez aos estudiosos e militantes desta que seria a área de estudos raciais e de comunidades rurais negras, questões muito próximas das que quase sempre envolveram a problemática indígena, obrigandoos a se manifestar sobre a questão fundiária, gerar respostas e instrumentos críticos para o diálogo com agências estatais e dialogar com interlocutores cujo quadro de referência não é o dos conceitos das ciências sociais, mas o das regras administrativas e do direito positivo.

Estamos diante, então, da possibilidade de avançar na crítica à tão clara repartição entre os chamados estudos étnicos e raciais, sendo que ela pode tomar duas direções, ou melhor, pode seguir a mesma direção em dois planos paralelos. O primeiro, está na suspeita sobre a evidência que assume a distinção entre índios e negros no que diz respeito a numerosas situações tematizadas pela história social. Num segundo plano, nos aproveitaremos dessa suspeita e da crítica a uma categoria de uso comum para apresentarmos algumas pistas para a investigação etnográfica.

\section{Rearranjos classificatórios}

A primeira proposição é a de que as unidades de descrição das populações submetidas respondem, ao custo de uma brutal redução de sua alteridade, às necessidades de produção de unidades genéricas de intervenção e controle social, sendo que tais unidades variam segundo aquelas necessidades de controle e domínio. Várias situações atuais de indistinção parecem estar relacionadas a essa plasticidade de categorias. Um dentre outros exemplos possíveis dessa plasticidade é vivido pelo grupo Pankararu, localizado no Brejo dos Padres, sertão pernambucano do São Francisco, para os quais a distinção entre índios e negros antes de ser puramente descritiva de uma realidade evidente é de natureza política e simbólica, servindo de termo acusatório e faccional. Na memória recuperada e na dinâmica vivida pelo grupo é impossível e inútil a tentativa de 
separar aqueles que podem ser perfeitamente reconhecidos como indígenas em oposição àqueles que sejam claramente negros (A rruti 1996).

Há outros exemplos em que a distinção entre índios e negros ultrapassa qualquer possibilidade de verificação objetiva, para assumir esse mesmo aspecto de operador de disputas familiares e faccionais. Os Negros do Riacho, localizados no Rio Grande do Norte e descritos por Assunção (1994), por exemplo, têm como princípio diferenciador interno fundamental a divisão entre os "da raça de negro" e os da "raça de caboclo", mas como numa imagem invertida da situação Pankararu, neste caso as acusações de impureza recaem sobre a ancestralidade indígena. Os A tikum, descritos por Grunewald (1993), localizados na Serra do U mã, em Floresta (PE), local em que as fontes históricas apontam a existência de quilombos históricos, são conhecidos pela população local como negros e não eram totalmente refratários a essa classificação até que na década de 40 conseguissem ser reconhecidos como "remanescentes indígenas" pelo extinto Serviço de Proteção ao Índio9.

A comunidade de M ocambo, localizada em Porto da Folha (SE), à beira do São Francisco, é outro exemplo que nos impõe essas questões. M ocambo possui 150 famílias negras, distribuídas em um vilarejo de uma única rua, cujas terras de trabalho, que ocupam há várias gerações, entram em litígio em 1992. A família que se diz proprietária inicia, então, uma ação de despejo e as famílias de M ocambo passam a ser submetidas a sucessivas expulsões, várias vezes operadas por força armada conjunta de jagunços daquela família e soldados da delegacia de Porto da Fol ha, além de serem assediadas constantemente por pistoleiros. Em conseqüência disso, em 1994, a Comissão Pastoral da Terra (CPT), respaldada no "Artigo 68", entra com um pedido de reconhecimento daquelas terras como terras tradicionais de remanescentes de quilombos. $\mathrm{O}$ interessante, no entanto, é que a área reivindicada pela comunidade acompanha o formato e se mantém fronteiriça à área Xocó, com os quais mantêm relações de parentesco, trocando dias de trabalho, terras de cultivo em épocas de seca ou de cheia etc. O próprio conflito com a família de proprietários tem início no ano seguinte, ao fim do qual, depois de um processo extremamente conflituoso, os X ocó conseguem a demarcação de suas terras (Arruti 1997).

As primeiras ações daquela família de fazendeiros já apontavam para uma percepção do problema em que índios e negros, juntos e indistintamente, eram acusados de invasores nos mesmos processos e intimados conjuntamente para depoimentos na J ustiça. Os X ocó10, depois de terem "emergido" na década de 30 como um dos desdobramentos daque- 
le "círculo de emergências" que já tinha alcançado os Pankararu (A rruti 1995), na década de 90 passam a participar ativamente do processo de reconhecimento do M ocambo, principalmente por intermédio de famílias de descendência tanto negra quanto indígena.

O interesse de situações como estas está em nos revelarem um aspecto do arbitrário que pode constituir a dicotomia índios/negros, não só em cada uma dessas etnografias, mas também quando passamos a explorar sua extensão histórica. A trajetória Pankararu é sugestiva. Como os outros grupos indígenas do Nordeste, eles "ressurgiram" nas primeiras décadas deste século, depois de terem sido extintos por volta da década de 1870, num momento em que se processava a extinção em massa dos aldeamentos indígenas na região (cf. Carneiro da Cunha 1992; Dantas et alii 1992). Como chamou a atenção Reis (1996), os verbos extinguir e destruir foram os mais usados pelos poderes coloniais para se relacionarem com índios e negros, não apenas com os "rebeldes" a que o autor faz referência.

A extinção daqueles aldeamentos, em regra, foi operada pelas Comissões de Demarcação das Terras Públicas (criadas nas províncias para dar conta das novas formas de apropriação do território estabelecidas com a lei de terras de 1850), que assumiram como uma de suas tarefas a identificação, localização e demarcação das terras dos aldeamentos. Essas demarcações eram precedidas por um relatório no qual o engenheiro responsável se manifestava sobre a situação do aldeamento e da população al deada, diagnosticando os seus problemas e o grau de "mistura" em que ela se encontrava, isto é, quanto aquelas populações já teriam sido absorvidas no mercado de mão-de-obra local e quanto elas mesmas já teriam absorvido, através de casamentos e laços de compadrio, a população regional não-indígena, enfim, seu grau de "mestiçagem". Como o diagnóstico era invariavelmente o de total "mistura" da população aldeada com os "nacionais", os aldeamentos eram considerados extintos e aquelas comissões (ou uma equipe formada após o fim dos seus trabaIhos) voltavam para proceder à sua repartição em lotes que deveriam, segundo a letra da lei, ser distribuídos entre os antigos aldeados e entre nacionais. No caso Pankararu isto significou a repartição de suas terras no que eles chamam de "linhas", a expulsão de um grande número de famílias indígenas e a entrega dos melhores lotes para a clientela do chefe político local e para um número indefinido de famílias de ex-escravos que acabavam de se emancipar.

O importante de se reter desse quadro, no entanto, é que na década em que se concentram essas extinções de aldeamentos, ocorrem simulta- 
neamente iniciativas de libertação de escravos através do Fundo de Emancipação11, uma intensa movimentação dos governos provinciais nordestinos no sentido de criar diferentes figuras de reunião e controle territorial e populacional, na forma de colônias (agrícolas, de "órphãos", de indigentes etc.), e algumas tentativas frustradas de imigração européia e norte-americana. A coincidência em um lapso de tempo relativamente curto dessas iniciativas revela um aspecto importante das estratégias ${ }^{12}$ de enfrentamento dos problemas decorrentes da libertação da mão-de-obra, em que ganha destaque a tentativa de substituição do domínio senhorial ${ }^{13}$ por formas públicas de controle da população, e que levam a um rearranjo das classificações a que elas estão submetidas. Extintos os aldeamentos e libertos os escravos, aquelas populações deixam de ser classificadas, para efeito dos mecanismos de controle, em termos de índios e negros, passando a figurar nos documentos como indigentes, órfãos, marginais, pobres, trabalhadores nacionais...

Há outros exemplos dessa forma flutuante por meio da qual a população foi sendo classificada, não tanto ou principalmente pela observação de suas características intrínsecas (fossem elas as mais obtusas ou estereotipadas), mas segundo os interesses e os instrumentos de dominação disponíveis. Ainda no Pernambuco da década de 1870, por exemplo, o aldeamento de Riacho do M ato é extinto para ser fundada em seu lugar a Colônia Agrícola de Socorro, criada para abrigar o grande número de retirantes, "indigentes emigrados", que afluíam ao local "quer do centro desta província, quer das circunvizinhas", conforme o Relatório do Presidente da Província de Pernambuco de 1878. Como não é mencionado o destino dos antigos aldeados de Riacho do Mato, o mais provável é que, como nos outros casos de extinção de aldeamentos, el es tenham permanecido no local, mas agora "reclassificados" nos documentos oficiais: através de um ato administrativo, deixam de ser "índios" para passarem a ser concebidos, contados e tratados como "indigentes".

Na São Paulo colonial, por exemplo, fica claro como essa flutuação pôde chegar muito próximo de uma dissolução das diferenças entre índios e negros, fundada justamente na forma pela qual aqueles grupos e indivíduos eram capturados pelas diferentes instituições do sistema de exploração da mão-de-obra. $\mathrm{Na}$ documentação da época, segundo M onteiro (1994:155), o termo índio referia-se apenas aos integrantes dos aldeamentos, reservando-se para a vasta maioria da população indígena não aldeada a denominação de "negros da terra"; em fins do século XVII, a denominação preferencial se simplificava para apenas "negros", só cedendo lugar a outras denominações no século seguinte, com o aumento do aflu- 
xo de escravos africanos nos plantéis paulistas (M onteiro 1994:165). M esmo aí, no entanto, e contra a legislação vigente, a confusão classificatória era perpetuada por estratégias de alteração física daquelas populações, quando os donos de plantéis de escravos incentivavam e muitas vezes forçavam os casamentos mistos "entre grupos étnicos distintos, entre índios dos aldeamentos e cativos, entre africanos e índios", como forma de transferir de mãos a atribuição do controle sobre aqueles indivíduos (M onteiro 1994:169-170)14.

Outras vezes é a própria dinâmica do enfrentamento que leva a que essa distinção seja temporária ou definitivamente superada, como no caso das revoltas, fugas e organização de mocambos. Assim é que no N ordeste, as bandeiras ou outros tipos de milícias particulares (que poderiam ser compostas, é bom lembrar, por índios e negros) (cf. Reis 1996:20), ampliando suas atribuições iniciais de captura de negros fugidos, avançam também sobre os aldeamentos indígenas à caça de índios para a escravização, encontrando em resposta, como no exemplo da invasão de 1763 da Vila de São Cristóvão, na Província de Sergipe, o levante conjunto daquelas populações. De forma semelhante, o massacre dos seguidores de Mestre Quiou, no início do século XIX em Pernambuco, pode ser lido tanto como uma situação de repressão a um movimento messiânico que ameaçava a ordem religiosa local, quanto como a repressão a um quilombo que ameaçava a estabilidade das propriedades escravagistas locais, dado o grande número de negros fugidos que para lá afluíram. Isso vale também para al guns dos grandes quilombos conhecidos, como o da Carlota ou Piolho em M ato Grosso, onde o alferes responsável por sua destruição, Francisco Pedro de M elo, relata ter encontrado apenas seis negros entre as 54 "presas" que ali fez, sendo o restante repartido entre 27 índios e índias e 21 "caborés", como eram conhecidos os mestiços de negros com índias (Oliveira 1951).

$\mathrm{Na}$ bibliografia emergente sobre quilombos essa questão é recorrente, ainda que continue ganhando um lugar apenas marginal nas interpretações. No A mazonas do final do século XVIII, por exemplo, mas também em várias outras regiões da A mérica, registram-se deserções em massa de índios para formar "mocambos" (Gomes 1996:49). Em exemplos complementares aos já levantados para o N ordeste, arrolam-se casos na Amazônia brasileira em que expedições inicialmente orientadas para o "resgate de índios" descobrem importantes quilombos ao longo dos rios, que compartilham com os primeiros "certas idéias de liberdade" (Gomes 1996:47). Reunidas essas situações, poderíamos nos perguntar, enfim, se a "identidade" que se supõe ter produzido entre negros (escra- 
vos ou livres), relacionada ao que os documentos oficiais viam como a "sedução" de certas idéias (Gomes 1996:51), não pode ter alcançado círculos maiores, rompendo com os limites sempre tão auto-evidentes do que se reconhece como "negro".

Tais brechas abertas nos discursos instituídos, permitem-nos colocar em suspenso a evidência desse recorte que se institucionalizou na dualidade étnico/racial, obrigando-nos a reconhecer que as diferentes instâncias de poder (estatais, religiosas, empresariais, privadas...), assim como as populações submetidas ou rebeladas contra elas, tenderam a ser bastante flexíveis no uso das classificações que os cientistas sociais e/ou a militância política mais tarde cristalizariam como realidades não discutidas e sobre as quais construi riam verdadei ros castel os interpretativos e conceituais. Os exemplos que evocamos têm o valor de nos chamar a atenção para o antigo (mas sempre atual izado) problema de enfrentar a documentação histórica ou os discursos no campo etnográfico sob a ilusão de que as mesmas palavras correspondem às mesmas coisas. Assim que nos apropriarmos rigorosamente dessas flutuações semânticas, que dermos inteligibilidade às suas sucessivas formas de variação, avançando na desnaturalização das categorias sociais, nos desobrigaremos também da estrita obediência aos ditames fundados sobre elas.

\section{De retornos e encruzilhadas}

Nossa segunda proposição é a de que o fenômeno atual que assistimos, do surgimento, resgate ou descoberta de comunidades remanescentes indígenas e de comunidades remanescentes de quilombo, corresponde à produção de novos sujeitos políticos, novas unidades de ação social, através de uma maximização da alteridade que, por um lado, subverte a indistinção de que falávamos e, por outro, intensifica a comparabilidade entre as duas situações.

$\mathrm{N}$ ão deve ter passado despercebido que o termo escolhido pelos legisladores na formulação do "Artigo 68" é o mesmo utilizado para descrever a situação das comunidades indígenas do N ordeste, principalmente pelos agentes que estavam em ação no momento das primeiras emergências, ao longo das décadas de 30 e 40 . A coincidência na opção que os agentes políticos, administrativos e judiciais fizeram pelo uso do mesmo termo-chave "remanescentes" para essas duas situações, aponta para a questão dos rearranjos classificatórios de que falávamos, mas também para a posição análoga, talvez homóloga, que essas situações ocupam 
diante das agências estatais e do senso comum acadêmico. Posição derivada em grande parte da força de evidência que essa noção parece carregar em si, no seu núcleo semântico básico e nebuloso, sobre o qual é preciso investir como única forma de controlar seu uso e fazê-la operar sob vigilância.

No processo de emergência dos índios do N ordeste o emprego do termo "remanescentes" respondeu, antes de mais nada, à necessidade de torná-los nomeáveis, adjetivando-os de forma que se fizessem visíveis e aceitáveis. A pergunta que parece ter se imposto aos que realizavam a mediação entre aquelas populações, o órgão indigenista e os "direitos", parece ter sido a de como, afinal, designar grupos de caboclos que se supunha terem ancestrais indígenas aldeados, sem incorrer na imprecisão, dificilmente aceita à primeira vista (não só na década de 30, mas ainda hoje), de simplesmente designá-los por índios, já que eles “não possuíam mais", como explicitou um daqueles mediadores, os "sinais externos" reconhecidos pela "ciência etnológica" (A rruti 1996).

Nos primeiros documentos do órgão indigenista e nos textos dos primeiros folcloristas/etnólogos sobre os grupos do Nordeste, fica clara a indecisão na escol ha da categoria atenuante mais adequada, levando à alternância e combinação de "caboclo", "descendentes indígenas", "remanescentes indígenas" e outras variantes, em que o "indígena" podia ser substituído por designações étnicas ou toponímicas. Essa indecisão, no entanto, com o tempo, cedeu lugar a um franco predomínio do termo "remanescentes", categoria que se mantém presente ainda hoje nos textos e discursos de autores e personagens que, através dela, acabam por criar uma categoria especial de índios e reconhecer um padrão particular de "indianidade" 15. Trata-se de uma adequação de vocabulário que permitiu a imediata inclusão daquelas populações no novo código de direitos instituído através do status jurídico de índios (decreto no 5.484 de 1928), mas sem ofender os "sinais externos" que indicavam o contrário.

Nesse contexto, referir-se a eles como descendentes indígenas parece não ter se adequado perfeitamente aos objetivos da mediação, já que, em seu uso comum¹6, a "descendência" pode estar referida a um lugar de origem (região ou nação), a uma raça, religião ou etnia, sem que isto implique que o sujeito dessa descendência seja efetivamente membro da categoria, grupo, lugar ou religião a que a descendência faz referência. M esmo no seu uso antropológico, a idéia de "descendência" deposita força na posição do ancestral, mais do que na daquele que dele descende, não estando implícita a transmissão imediata de direitos. Estabelece-se, assim, um compromisso entre uma visão culturalista e outra legal de cul- 
tura, de tradição e de identidade: enquanto, de um lado, o culturalismo não admite reconhecer naquela ausência de cultura e tradições puras um valor etnológico próprio, mas apenas relativo ao passado, tomando aqueles grupos em termos de sincretismo e val orizando-os, portanto, não como índios, mas como representantes típicos de uma herança cultural em desaparecimento; de outro, o código civil e o decreto de 1928 afirmam direitos aos indígenas pensados em sua presencialidade, não introduzindo nesses direitos qualquer sentido puramente hereditário. Para se ter direitos e tutela era preciso ser silvícola, e não apenas descender deles.

A fórmula "remanescentes" funciona como a solução classificatória mediante a qual se admite a presencialidade do estado de índio naqueles grupos, sem deixar de reconhecer neles uma queda com relação ao modelo original: os remanescentes são uma espécie de índios caídos do nosso céu de mitos nacionais e acadêmicos, "sobras", "restos", "sobejos" (M irador 1980), aos quais se reconhecem profundas e talvez irremediáveis perdas culturais, mas que não negam seus direitos ao estatuto legal. Uma solução classificatória sustentada por uma narrativa bem delimitada (ainda que implícita), que fala do destino daqueles grupos em termos de um processo evolutivo: do estado de "bom selvagem", puro, natural, até o de civilizado ou, caso não fossem submetidos à tutela que devia orientar e regular essa transição, ao estatuto de degradado, que perde sua cultura e não consegue ser inteiramente absorvido pela civilização, passando a ocupar um espaço dedicado aos excluídos e desajustados.

$\mathrm{M}$ as, de alguma forma, ao apontar para os seus laços com o passado e não com o futuro dessa linha mutacional, o termo "remanescentes" reserva ou resgata para aqueles grupos al guma positividade, sem romper com a narrativa básica, fatalista e linear. Esses pressupostos colocam no núcleo de definição daqueles grupos uma historicidade que remete sempre ao par memória-direitos, em alternativa e, por vezes (no caso indígena), oposição, ao par cultura-proteção: em se tratando de remanescentes o que está em jogo é a manutenção de um território como reconhecimento do processo histórico de espoliação.

Pode-se reconhecer no caso das comunidades negras função semeIhante. No "Artigo 68", o termo "remanescentes" também surge para resolver a difícil relação de continuidade e descontinuidade com o passado histórico, em que a descendência não parece ser um laço suficiente. De forma semelhante à dos grupos indígenas, o emprego do termo impli$\mathrm{ca}$, no limite, reconhecer nas comunidades presentes formas apenas atualizadas dos antigos quilombos, ainda que em função do lugar espelhado que o negro ocupa com relação ao índio, isso inverta o valor atribuído 
àquelas "sobras" e "restos" de formas antepassadas. Se entre os indigenistas o termo serviu para relativizar, na prática (ainda que por caminhos tortuosos, que acabavam por reafirmar a crença no modelo), o exótico, o isolamento, a continuidade de uma carga cultural homogênea e autônoma, no caso das comunidades negras rurais, ou melhor, para a representação que se passa a fazer delas, seu emprego pode significar justamente a afirmação ou produção dessas idéias. Principalmente porque, a partir da década de 70, quando a renovação historiográfica se voltou para os movimentos populares e para a "história dos de baixo" e da sua "resistência", a retomada do tema dos quilombos transformou-os em símbolos da recusa absoluta à ordem escravocrata, oligárquica e, em alguns casos, do próprio capitalismo.

Ao serem identificadas como "remanescentes", aquelas comunidades em lugar de representarem os que estão presos às relações arcaicas de produção e reprodução social, aos misticismos e aos atavismos próprios do mundo rural, ou ainda os que, na sua ignorância, são incapazes de uma militância efetiva pela causa negra, elas passam a ser reconhecidas como símbolo de uma identidade, de uma cultura e, sobretudo, de um modelo de luta e militância negra, dando ao termo uma positividade que no caso indígena é apenas consentida.

Com efeito, o uso da noção, em ambos os casos, implica, para a população que o assume (indígena ou negra), a possibilidade de ocupar um novo lugar na relação com seus vizinhos, na política local, diante dos órgãos e políticas governamentais, no imaginário nacional e, finalmente, no seu próprio imaginário. Lugar a partir do qual é possível produzir um retorno com relação àquele "eixo de mutações" de que falávamos inicialmente. Em ambos os casos, trata-se de reconhecer naqueles grupos, até então marginais, um valor cultural absolutamente novo que, por ter origem em um outro quadro de referências (a tal cosmologia nacional, savante), era até então desconhecido deles mesmos. E aqui chegamos ao ponto fundamental.

O esforço de crítica e historicização de categorias sociais, que nos levou a esta incursão pelas implicações da noção de "remanescentes", não deve ser reduzido à simples observação de que as "palavras" podem ser inventadas, emprestadas e ganhar novos sentidos, o que transformaria este num morno exercício de etimologia. Talvez tenha alguma utilidade lembrar que o trabal ho genealógico, neste caso, é apenas o ponto de partida de uma crítica à idéia de que tais denominações são simples institucionalizações de divisões espontâneas do mundo social, ou, de outra forma, batismos de seres naturais. A história dos nomes é também a his- 
tória dos seres e instituições que eles nomeiam, do seu surgimento, desaparecimento e mutação. Afirmar que o termo "remanescente" não era conhecido ou usado pelos remanescentes até que ele lhes fosse "comunicado" é apenas uma tautologia se não avançarmos até a idéia de que a criação do nome está ligada ao próprio surgimento da coisa ${ }^{17}$.

No processo (na maioria, se não na totalidade das vezes, conflituoso) de nomeação de um grupo como "remanescente", produzem-se uma série de mudanças que atingem aquelas comunidades, tanto na sua relação com os que as rodeiam - sejam as populações vizinhas, os poderes locais ou os aparel hos de Estado - , quanto nas relações entre seus próprios atores, com acomodações, disputas e muitas vezes a própria criação de chefias e formas de ordenamento político, com a alteração dos significados atribuídos às festas e rituais, com a reelaboração da memória e com a alteração do status dos guardadores da memória, que passam a desempenhar um papel sem precedentes na vida do grupo. A pesar das exigências do termo, os "remanescentes" não são sobras de antigos quilombos prontos para serem identificados como tais, presos aos fatos do passado por uma continuidade evidente e prontamente resgatada na "memória coletiva" do grupo.

Independente de "como de fato foi" no passado, os laços das comunidades atuais com grupos do passado precisam ser produzidos hoje, através da seleção e recriação de elementos da memória, de traços culturais que sirvam como os "sinais externos" reconhecidos pelos mediadores e o órgão que tem a autoridade de nomeação. As diferenças que podiam até então distingui-los da população local na forma de estigmas passam a ganhar positividade, e os próprios termos "negro" ou "preto", muitas vezes recusados até pouco tempo antes da adoção da identidade de remanescentes, passam a ser adotados. As fronteiras entre quem é e quem não é da comunidade, quase sempre muito porosas, passam a ganhar rigidez e novos critérios de distinção, genealogias e parentescos horizontais passam a ser recuperados como formas de comprovação da inclusão ou não de indivíduos na coletividade. Ao mesmo tempo, a maior visibilidade do grupo Ihe dá uma nova posição em face do jogo político municipal e, por vezes, estadual. Enfim, a adoção da identidade de remanescentes por uma determinada coletividade, ainda que possa fazer referência a uma realidade comprovável, é, com muito mais força, a produção dessa própria realidade. 


\section{Comunidades emergentes}

A relevância do movimento analítico que aproxima as "comunidades remanescentes de quilombos" da noção de "etnicidade" está, portanto, na problematização do seu processo de autoconstituição como grupos sociais e culturais diferenciados, ou, em outros termos, no que a literatura antropológica convencionou chamar de etnogênese.

$M$ as aqui é preciso fazer referência a algumas leituras confusas que podem ser produzidas a partir desse movimento analítico. Em um texto de V. Stolcke, por exemplo, a opção pela perspectiva étnica, pensada no contexto de debates acerca do racismo, é vista apenas como a produção de um "eufemismo politicamente carregado", já que seu papel seria unicamente o de enfatizar o caráter cultural e ideológico das discriminações raciais, abandonando o campo das referências biológicas para adotar um vocabulário academicamente mais rigoroso e comprometido com uma interpretação histórica e cultural dos agrupamentos humanos (Stolcke 1991). A autora se pergunta se, reconhecida a idéia de que a raça também é histórica e culturalmente construída, restaria alguma diferença sociológica significativa entre "raça", "etnia" e, avançando mais um pouco, "classe". Afirma que a opção pela etnia corresponderia a uma postura política conservadora, através da qual chegaríamos a uma paradoxal "naturalização da cultura", em que os preconceitos seriam justificados por uma pretensa relativização das xenofobias em geral, ao mesmo tempo que evitaria o tema fundamental das relações de dominação econômica e social. Uma crítica que perde de vista a grande variedade de situações em que estão envolvidos os processos de criação de fronteiras sociais e culturais, que não se traduzem nem em uma questão de cor, nem em uma questão socioeconômica.

Banton (1979), por exemplo, ao trabalhar com o caso do racismo contra negros americanos, busca estabelecer correspondências com outros exemplos para associá-lo a um leque maior de questões. Como resultado desse movimento, propõe pensar a oposição entre raça e etnicidade em termos de valor social, já que o uso da primeira noção refletiria as tendências negativas de dissolução e exclusão (os estudos sobre o racismo seriam sempre sobre a natureza e o poder das maiorias), enquanto o segundo expressaria as tendências positivas de identificação e inclusão (os estudos étnicos iluminando o poder que pode ser mobilizado pelas minorias). Ou seja, a diferença no uso das noções estaria associada a uma perspectiva que atribui maior ou menor ênfase às questões de classificação social em termos de mobilização de grupos e das formas e valores 
que esta pode assumir. Segundo Banton, na passagem do racial ao étnico, os signos de distinção teriam seus sinais invertidos, deixando de representar estigmas, para assumir um sentido de solidariedade e identificação. Nesse sentido, um grupo racial tornar-se-ia um grupo étnico a partir do momento em que, aceitando a distinção que lhe é imposta pela maioria, passa a utilizar-se politicamente dela na formação de agrupamentos autônomos ou com interesses e reivindicações comuns. Uma resposta útil, mas ainda insuficiente para pensarmos a situação dos remanescentes, como veremos.

Outro tipo de confusão que pode envolver a conversão de uma abordagem em termos de raça para uma perspectiva em termos de etnicidade é apresentado por M aria de Lourdes Bandeira (1988), quando afirma que nos trabal hos sobre grupos rurais negros a "busca da etnicidade" surge associada à ênfase do antropólogo nas "formas culturais" que marcariam as especificidades "objetivas" dos grupos étnicos, tais formas estando associadas à "persistência de traços culturais originários da África" (Bandeira 1988:21). Um efeito que, aparentemente, se deve à tentativa de propor uma leitura diferente para a história e o destino daquelas populações, mas que naturaliza as diferenças e sua continuidade com o passado. Como foi dito com relação à posição de Banton, mas sobretudo voltando ao ponto fundamental destacado por Weber (1991), o sociologicamente relevante no uso da categoria etnicidade é sua remissão ao movimento de um determinado agregado no sentido da constituição de uma unidade política. A etnicidade não marcaria, portanto, o reconhecimento de semel hanças previamente dadas, inscritas naturalmente nos corpos e nos costumes e cuja explicação estaria no passado, mas uma atitude positiva e propositiva, através da qual seriam produzidas demandas e um projeto comum ${ }^{18}$, ou seja, cuja vinculação e razão de ser está no futuro.

O que aquelas duas posições que apresentamos como problemáticas têm em comum é perderem de vista a ruptura produzida por Barth (1969) e Cohen (1974) e por todo um campo de discussões já plenamente estabelecido, cujas referências mais freqüentes no Brasil são os trabalhos de Cardoso de Oliveira (1976 [1971]) e Carneiro da Cunha (1986 [1979]). Se o uso mais freqüente da noção de grupo étnico nas ciências sociais esteve ligado ao uso popular da expressão, que remete ao significado grego "grupo de pessoas de mesma raça ou nacionalidade que apresentam uma cultura comum e distinta" (Keyes 1976), tal noção tornou-se incapaz de continuar dando conta das necessidades analíticas dos antropólogos contemporâneos (Keyes cita como primeiro exemplo disso a análise dos Kachin realizada por Leach em 1954), quando, então, ficou claro não exis- 
tirem traços culturais que possam ser tomados como "primordiais". Daí a tendência entre antropólogos e sociólogos, inaugurada pelo trabalho de Barth (1969), de distinguir o conceito de grupo étnico de qualquer significado cultural inerente, para vê-lo como uma entidade social que emerge da diferenciação estrutural de grupos em interação, um modo de construir oposições e classificar pessoas, em que o social e simbolicamente relevantes são as "fronteiras" desses grupos - o que em uma primeira formulação era apresentado como "o problema dos limites do grupo político" (cf. Fortes e Evans-Pritchard 1981[1940]) - e os mecanismos de criar e manter tais fronteiras (Barth 1969).

Assim, falar de grupo étnico para descrever as comunidades rurais negras historicamente vinculadas aos quilombos (ou outras formas que Ihe tenham correspondido) não deve levar à busca de "pequenas áfricas", que poderia remeter a uma idéia de resistência cuja contrapartida seria a conservação e/ou o retorno ao passado. Mesmo na análise de Cohen (1974) sobre o fenômeno da "retribalização" nas cidades africanas, o que se encontra ao explorar a etnicidade são formas de organização social em que as populações articulam antigos costumes e formas de relacionamento social com as novas regras a que estão submetidas, de uma forma dinâmica, em função de uma auto-organização em termos políticos. Essa reorganização, nos exemplos trabalhados por Barth e Cohen, não responderia nem a recortes tão genéricos, como o de cor19, nem remeteria a grupos tão bem delineados quanto os descritos pela antropologia estrutural-funcionalista. Ainda que os conteúdos culturais possam variar no tempo, no espaço e na própria origem dos indivíduos que venham a compor o grupo étnico, a análise deve recair sobre os mecanismos de criação e/ou manutenção de uma forma organizacional que prescreve padrões unificados de interação e que regula quem faz e quem não faz parte do grupo, além das relações entre aqueles que fazem parte e entre estes e aqueles que não fazem.

O que os trabalhos sobre etnogênese enfatizam (Sider 1976; Gallagher 1974; Despres 1975) e que marca os novos estudos sobre os grupos indígenas do N ordeste, pensados não mais como remanescentes, mas como emergentes, é que tais fronteiras podem ser criadas ou mudar de natureza quando entra em cena a disputa por recursos, em especial os recursos fundiários. Nas situações de emergência de grupos indígenas no Nordeste, a identidade genérica de "índios" está sempre associada aos "direitos" a que este rótulo faz referência e, em todas as situações já trabalhadas, a recuperação de uma identidade indígena (que é, simultaneamente, a produção de uma identidade Pankararu, Xocó, Potiguara 
etc.) esteve associada à descoberta da existência desses "direitos". É simultaneamente ao processo de descoberta dos direitos que aquelas fronteiras, sempre tão porosas e atravessadas pela "mistura" e pelo "sincretismo", mudam de consistência, que o arranjo político interno às comunidades passa por transformações no sentido de uma maior formalização e que a relação com a memória e com as "tradições" também passa por profundas transformações.

O atual processo de atribuição de "direitos" às "comunidades remanescentes de quilombos" opera um tipo de transformação semelhante entre as comunidades rurais negras, dando origem também a processos de etnogênese. Como apontou Sider (1976), se o etnocídio é o extermínio sistemático de um estilo de vida, em oposição a ele, a construção fraternal de uma autoconsciência e de uma identidade coletiva (de base racial e/ou histórica) contra a ação de um Estado Nacional opressor, com vistas a ganhos políticos, entre os quais pode-se encontrar alguma expectativa de autodeterminação, deve ser chamada de etnogênese. M as, ressalta Sider, os grupos étnicos não são perseverados ou preservados, e sim criados. Isso faz com que o processo de localização e mobilização para o reconhecimento de "remanescentes" fuja do universo das "questões de raça", para figurar no plano não só da etnicidade, mas da etnogênese, já que não se trata de recuperar etnias, no sentido convencional, mas produzir novos sujeitos políticos, que se organizam mobilizando uma série de elementos de identidade comum e de caráter localizado que remetem a um mesmo passado de escravidão e submissão, a fim de alcançarem novos recursos, em particular os de natureza territorial.

Tanto nos casos mais conhecidos, como das comunidades de Kalunga (GO), Rio da Rãs (BA), Oriximiná (PA) e Vale da Ribeira (SP), quanto em situações ainda muito pouco estudadas, como as de M ocambo (SE) e Sacotiaba (BA), com as quais tive contato, o processo de assunção da identidade de "remanescentes" teve início com a disputa por recursos (normalmente traduzidos em termos territoriais), e só então, concomitantemente ou ainda mais tarde, quando o instrumento de luta privilegiado passa a ser o "Artigo 68", as questões de cultura e origem comum emergem, passando a ser plenamente tematizadas pela comunidade e tornando-se objeto de reflexão para o próprio grupo. A mobilização desses elementos de identidade leva a uma nova relação com o passado e com as "reminiscências" de que falou W. Benjamin, num esforço de reconstrução de uma continuidade na maioria das vezes perdida, levando ao que H obsbawm e Ranger chamaram de "invenção de tradição", isto é, uma reapropriação de vel hos modelos ou antigos elementos de cultura e de 
memória para novos fins, em que o passado serve como repertório de símbolos, rituais e personagens exemplares que até então poderiam ser desconhecidos pela maior parte da comunidade.

M as ao falarmos de invenção cultural como indissociável da noção de etnogênese, é preciso estarmos atentos para o caráter de invenção que constitui qualquer agrupamento social e a própria definição de sociedade (Wolf 1988), para não se atribuir a esse movimento analítico um sentido negativo, associado às idéias de falsidade, manipulação, artificialismo etc. Como destacou Oliveira Filho (1993) com relação às emergências indígenas, seu caráter pragmático é inegável, mas seria um equívoco reduzir tais processos de etnogênese a este único aspecto, já que as lutas comuns e os rituais retomados ou inventados (mas de qualquer forma partilhados) contribuem para dotar aquelas identidades de uma grande importância normativa, afetiva e valorativa, criando as condições de possibilidade para que surja em torno daqueles sujeitos históricos uma “comunidade imaginada" (A nderson 1989), isto é, um sentimento de unidade, de pertencimento e destino comuns (Oliveira Filho 1993:vii).

A lém disso, reapropriando-nos das críticas de Keyes (1976) a Barth (seria, no entanto, mais adequado dirigi-las às reapropriações e vulgarização das proposições de Barth), é necessário reconhecer que, se os movimentos de re-significação e mesmo de adoção e empréstimo de atributos identitários - sejam eles elementos de cultura ou de origem-históriamemória comuns - são situacionais, os próprios elementos e a possibilidade de operar essas re-significações, adoções ou empréstimos não o são (cf. também os problemas empíricos levantados por Galaty 1982). Como aponta Keyes, na prática, mesmo os autores interessados primariamente na diferenciação estrutural de grupo étnico, empregam algum "dado" cultural para definir sua natureza, como aliás é sempre reivindicado pelos próprios observados. A "plasticidade identitária” formadora desses grupos permite, efetivamente, que eles "resgatem", "recuperem", elementos substantivos de identidade que passam a integrar seus processos de emergência, mas como "matérias-primas" que precisam ser manufaturadas pelas forças mobilizadas no seu interior, na forma de desejos coletivos.

Assim, as críticas recentes a uma perspectiva exclusivamente pragmática não devem desenhar um recuo essencialista, da mesma forma que as noções de etnogênese e de invenção não devem descartar a consideração dos elementos identitários eles mesmos, nem negar sua legitimidade. No lugar dessa dicotomia, devemos reconhecer a relação dialética que se estabelece entre o herdado e o projetado, entre passado e futuro que, no curso das interações, submete elementos de cultura, de estrutura 
e de memória a re-significações e re-atuações. A constatação das permanências, dos sincretismos e das contrastividades não serve mais como resposta, mas como ponto de partida.

É apenas aparentemente paradoxal reconhecer que identidades legítimas foram inventadas um dia, ou que tradições, memórias e identidades inventadas são legítimas, já que, como apontam H obsbawm e Ranger, as rupturas estão até mesmo nos corpus ou topoi mais genuinamente contínuos com relação a uma tradição histórica. O que marca essas rupturas e a presença da inventividade social é o fato de que toda tentativa de preservar ou recuperar tradições está, dada a impossibilidade de manter o passado como al go permanentemente vivido, destinada a se transformar em "tradição inventada". A o tematizar e dar caráter reflexivo à sua cultura e à sua ligação com o passado, o grupo está retirando do fluxo contínuo aquilo que deseja preservar, transformar em símbolo e, por isso, fixar, rompendo justamente com seu caráter de hábito que submete aqueles elementos a uma permanente mutação20, para alçá-los a um novo estatuto, o de uma tradição, nesse sentido sempre inventada.

A reação ao emprego da idéia de invenção (fundamental para entendermos o processo a que essas comunidades estão submetidas hoje) tem sua fonte na adesão a uma teoria da história, comum à linguagem corrente, que supõe a partir das palavras que designam instituições ou entidades coletivas abstratas, a existência de sujeitos históricos capazes de originar e realizar os seus próprios fins (Bourdieu 1989:75). A mágica desse procedimento seria a de transformar o fim da história no fim da ação histórica, naturalizando a relação entre o que a história fez dos sujeitos e dos grupos e o que ela Ihes pede para fazer. Hoje a história pede aos "remanescentes" que eles representem (no sentido político e teatral) o que se supõe ter sido o objetivo heróico dos quilombos, transformados em ícones da luta negra, independente do que a história posteriormente tenha feito daquelas comunidades. Por isso, o reconhecimento como "remanescente", que para muitas comunidades tem se mostrado uma via importante (algumas vezes a única via) de garantir suas terras e sua voz política, antes de ser um ato natural de identificação do que é dado, ao contrário, as obriga a compreender as transformações operadas na ideologia dominante para que possam aceitar e se adaptar a esses novos papéis. M uitas vezes isso significa fazer opções a partir do que poderíamos pensar enquanto uma "plasticidade identitária" que se abre a outras possibilidades, só então descartadas.

Como lembra Bourdieu, a história objetivada, institucionalizada, só se torna atuada e atuante se o posto ou a designação ou a identidade em 
causa encontra quem a ache interessante e nela veja vantagens, mas também que nela possa se reconhecer para se responsabilizar por ela e a assumir, fazendo com que os agentes ou grupos entrem na pele do personagem social que deles se espera e que eles esperam de si próprios (Bourdieu 1989:87). Trata-se da adequação dos corpos em que está inscrita uma determinada história às novas funções e leituras que lhe são atribuídas. Essa história deve ser tanto apreendida quanto aprendida, retomada, revitalizada, retirada da dinâmica dos corpos que, eventualmente, a levaria por outros caminhos para assumir suas novas funções.

$M$ as se essa dialética, no caso dos remanescentes indígenas, encontrou respaldo em um estereótipo definido a partir de modelos etnológicos amplamente difundidos que encontraram no Toré a sua forma-síntese ${ }^{21}$, no caso dos remanescentes de quilombos, pela falta de tais modelos prontamente disponíveis, essa dialética é paradoxalmente mais clara. A importância de percebê-los como emergentes está em reconhecer que o seu lugar, porque ainda mal definido tanto com relação às condições de acesso aos seus novos direitos, quanto às condições de exercício de sua nova identidade, antes de fazer aqueles que o ocupam, ainda está por ser feito por aqueles que conseguirem ocupá-lo. Por sua vez, a definição mais favorável daquilo que devem ser não depende apenas deles ou dos seus opositores, mas também do estado da correlação de forças em que aquelas comunidades e seus mediadores e concorrentes a mediadores estão inseridos e na qual o papel interpretativo do antropólogo e do historiador parece ter destaque. Reconhecer a sua construtividade, ligada à "plasticidade identitária" que marca boa parte dessas comunidades, antes de vir a deslegitimar o lugar dos pretendentes, serve como um sinal de alerta para aqueles que operam na correlação de forças que definirá qual é este lugar e quais as formas de acesso a ele.

Recebido em 12 de junho de 1997

Reapresentado em 21 de julho de 1997

A provado em 6 de agosto de 1997

J osé Maurício Andion Arruti é formado em história pela UFF, mestre e doutorando em antropologia social pelo M useu Nacional, UFRJ e professor substituto de antropologia da UFF. Tem pesquisa em história indígena do nordeste brasileiro e trabal ho de campo entre os Pankararu (PE). A tualmente desenvolve pesquisa sobre "comunidades remanescentes de quilombos", com trabalho de campo em Sergipe e Rio de J aneiro. E-mail: arruti@ax.apc.org. 


\section{Notas}

* Este artigo foi escrito originalmente como trabalho final de um curso ministrado no 1o semestre de 1996 pelo prof. J oão Pacheco de Oliveira Filho. Foi apresentado na reunião da ABA, em Salvador, no mesmo ano (cf. nota 17) e no 1o semestre de 1997 foi discutido pela turma do seminário de doutorado ministrado pelo prof. Otávio Velho, quando, então, pude me beneficiar de suas críticas e de meus colegas Emerson Giumbelli, Fabíola Rohden e Kátia Maria Pereira de Almeida. Agradeço também as muitas sugestões do prof. M arcio Goldman. As falhas, obviamente, continuam a ser de minha inteira responsabilidade.

10 texto do Artigo 68 das Disposições Constitucionais Transitórias é o seguinte: "A os remanescentes das comunidades dos quilombos que estejam ocupando suas terras é reconhecida a propriedade definitiva, devendo ao Estado emitir-Ihes os títulos respectivos".

2 A necessidade ou não de sua regulamentação foi também objeto de debate, mas apesar dos argumentos por sua auto-aplicabilidade, as poucas tentativas concretas de beneficiar comunidades de remanescentes esbarraram na posição de juízes que al egavam não possuir instrumentos básicos para a orientação de seus pronunciamentos.

3 Veja-se a importante revisão crítica de Eder Sader e Maria Célia Paoli (1986) sobre a noção de "classes populares", em que os autores exploram representações intelectuais mais contemporâneas que tendem a confundi-la ou reduzila à idéia de "classes trabalhadoras", apesar e sob o lamento da sua diversidade subjacente. Há, no entanto, um enorme campo de investimento muito pouco explorado sobre a relação entre esses discursos acerca do "popular" e formas de discurso sobre o outro, como o "orientalismo" (Said 1990) ou "terceiro-mundismo" (A hmad 1988). Como nesses últimos casos, a disciplina escol hida para a investigação do popular, o folclore, tendeu a substancializar uma síntese que é produto de seu próprio movimento analítico, ajudando a conhecer menos o objeto do discurso que o seu formulador, protagonistas de uma relação de conhecimento, mas sobretudo de poder.

4 A qui também seria necessário qualificar o uso destes termos no Brasil, mas para a argumentação desenvolvida basta lembrar que os termos integração (e/ou assimilação) e acampesinamento remetem a abordagens do "contato" com ênfases distintas, num caso mais culturalista e noutro mais sociológica, representadas, respectivamente, por Darcy Ribeiro (1978) - volume que reúne textos produzidos desde a década de 50 - e por Roberto Cardoso de Oliveira (1978) - volume reunindo textos produzidos desde a década de 60. 
5 Já foi produzido sobre o tema um número razoável de trabalhos monográficos com ênfases no processo de emergência e na questão da invenção cultural dos grupos indígenas do N ordeste, como em Valle (1993); Batista (1992); Barreto Filho (1992); Souza (1992); Grunewald (1993); e M artins (1994); interpretações gerais, basicamente, em Carvalho (1984); Dantas et alii (1992); e Oliveira Filho (1993); e análises que pretendem interpretações regionais com ênfases temáticas a partir de análises monográficas, como em Peres (1992) e Arruti (1996).

6 Estes textos (mais um em colaboração com R. Slenes) foram republicados em forma de livro em Vogt e Fry (1996). N este volume os autores acrescentaram também uma espécie de posfácio, no qual tentam trazer tais textos para o contexto do debate atual sobre comunidades remanescentes de quilombos. Uma tarefa, no entanto, difícil.

7 É interessante perceber como a heterodoxia desses objetos foi revelada justamente por uma espécie de desvio no interior de tradições institucionais. Assim, da mesma forma que os estudos com um novo olhar sobre comunidades indígenas camponesas se concentraram no Museu Nacional, essa nova série de estudos sobre negros rurais tem início na USP.

8 Existe um único exemplo de trabalho já finalizado de autoria de antropólogos sobre uma "comunidade remanescente de quilombos", realizado no contexto de reconhecimento dos direitos da comunidade a sua terras tradicionais (Carvalho 1996). É mesmo possível que boa parte das novidades que venham a surgir daqui em diante nessa área seja produto de situação semelhante, o que nos aponta uma característica interessante: a "encomenda" e o diálogo com o campo jurídico não aparecem como um dilema de adequação, mas como uma marca de origem desse campo de estudos.

9 A pesar de Grunewald não enfatizar esse aspecto na sua dissertação, uma idéia jocosa apresentada por ele durante o GT sobre indigenismo na ABA, em 1994, revela o alcance dessa plasticidade étnica que estamos sugerindo ser de interesse antropológico e político. Segundo aquele pesquisador, os “caboclos da Serra do Umã" poderiam não ter se transformado em Atikum, se a agência de contato na época de sua mobilização política não tivesse sido o Serviço de Proteção ao Índio, mas um possível Serviço de Proteção ao N egro, caso ele tivesse existido, já que na ascendência do grupo podem-se encontrar essas duas fontes identitárias.

10 A população Xocó distribui-se por cerca de 200 famílias, divididas entre uma área de "beira" (a "Área Caiçara", com 4.220ha) e uma área de ilha (a área Ilha de São Pedro, com 97ha). Com o progressivo e violento apossamento de suas terras, a partir de 1850 pelos poderes locais, parte de sua população começa a migrar para junto dos Cariri (dando origem aos atuais Kariri-X ocó, localizados poucos quilômetros abaixo, às margens do rio São Francisco, no lado alagoano) e a parte do grupo que permanece começa a fazer viagens à capital estadual e depois ao Rio de J aneiro, em busca de apoio, sempre sem sucesso. $\mathrm{N}$ a década de 
30 os Xocó têm acesso ao órgão indigenista oficial e o grupo é reconhecido como indígena, mas o conflito progride até que, nas décadas de 60 e 70, depois de alcançar graves proporções, inclusive com violências contra representantes da Igreja, a Funai intervém comprando as terras da Ilha em 1984. Seguiram-se fortes represálias à população X ocó, que respondeu com a invasão da terra "Caiçara", provocando a intervenção de sucessivas instâncias de poder: polícia militar, J ustiça estadual, M inistério Público Federal e, finalmente, a Procuradoria da República, até que em 1988 a Funai é intimada a demarcar a terra Xocó, o que só ocorre porém em 1991 (cf. Dantas e Dallari 1980; Peti 1993).

$11 \mathrm{Na}$ lei de 1871 estabeleceu-se, além do que ficou conhecido como a "lei do ventre livre", a criação de um mecanismo de financiamento estatal para a libertação antecipada de escravos, através de um fundo composto de impostos sobre compra e venda de escravos e de uma loteria, dentre outros, conhecido como "Fundo de Emancipação". A arrecadação deste fundo deveria ser empregada segundo as "listas" organizadas por comissões municipais criadas especificamente para este fim. Uma série de problemas, no entanto, que iam do montante que se conseguia arrecadar até a sua gestão, passando pelo processo de formulação das "listas", que ficava nas mãos dos poderes locais, muito rapidamente vieram a desacreditar o "Fundo", condenando-o não apenas diante dos ol hos dos abolicionistas, mas também dos historiadores que Ihes seguiram. O seu fracasso como proposta global e em seus efeitos quantitativos em face do problema maior da abolição não deveria, no entanto, ser obstáculo para uma consideração mais justa sobre seus possíveis impactos em situações circunscritas, como a de localidades e províncias já economicamente marginais naquela época.

12 A noção de "estratégia" , conforme usada por Bourdieu (1989:82) para descrever ações individuais e que aqui adaptamos aos nossos interesses, antes de apontar para uma ação consciente, é um recurso que permite fugir tanto de uma visão finalista quanto desinteressada da ação social, indicando a possibilidade de articulação entre investimentos que, apesar de não serem regidos por um cálculo plenamente consciente, que só poderia remeter a fantasmagorias como “o Estado" ou "a classe dominante", muito menos são arbitrários ou aleatórios, estando vinculados a posturas e habitus comuns que vão ganhando sentido e unidade através da sua própria prática.

13 No caso dos aldeamentos, também o domínio que o missionário ou o capitão-mor exerciam sobre os aldeados não estava muito distante do controle senhorial sobre a senzala (cf., p. ex., M onteiro 1994:151).

${ }^{14} \mathrm{~N}$ ão deve ser inoportuno lembrar que as próprias classificações internas aos grupos indígenas respondiam ao mesmo tipo de lógica, em que valia mais o tipo de relação que se queria impor do que a desinteressada observação do mundo: a dualidade entre Tupi e Tapuia respondia ao jogo classificatório entre aqueles grupos já submetidos ou com os quais já se estabelecera uma relação estável e aqueles mais bárbaros, indomáveis, traiçoeiros, que seria preciso reprimir ou apresar através das bandeiras. M ais tarde, o termo genérico Tapuia seria substituído 
por outros que, no entanto, guardariam função semelhante, como Cariri, Carnijó, Aimoré etc, segundo a região (cf. Dantas et alii 1992; Monteiro 1994).

15 O termo “indianidade”, conforme proposto por Oliveira Filho (1988), designa uma determinada forma de ser e de conceber-se "índio", no sentido genérico do termo, construída em interação com o órgão tutelar. Associado a uma determinada imagem do que deve ser o "índio", a "indianidade" é um padrão de interação e de comportamento criado, basicamente, através da instituição e atuação de aparelhos burocráticos de origem estatal, que estabelecem procedimentos estandartizados para lidar com a diversidade indígena. A indianidade tem lugar, justamente, quando o modelo imposto pelo órgão acaba por se impor à realidade e o indivíduo, ou grupo étnico, passa a assumi-lo como sua realidade ou como seu próprio padrão de comportamento. Ainda que esse movimento entre homogeneidade e heterogeneidade não seja linear e que mesmo no interior da padronização exista o movimento no sentido da diferenciação, a importância do conceito de indianidade está na sua identificação de um dos efeitos fundamentais da relação entre grupos indígenas e aparelhos de Estado.

16 Neste caso, os vocabulários sociológico e antropológico também se aproximam do uso vulgar da categoria (cf. Freedman 1986).

17 Devo agradecer as provocações e o debate desencadeado pelas enfáticas intervenções de Valdélio Santos Silva e J osé J orge de Carvalho, durante a apresentação de uma primeira versão deste trabalho no encontro da ABA de 1996. A partir daí me vi estimulado a desenvolver boa parte das reflexões que se seguem.

18 Falar dessa unidade de ação não implica desconhecer todo o processo de disputas internas que a própria instituição do grupo político, normalmente, acarreta através de diferentes formas de faccionalismos e disputas internas.

19 Um recorte que em situações de sociedades complexas (como a dos EUA) significaria supor como um mesmo grupo, a partir de um contraste com a população branca, o que na verdade é uma grande população cultural, social e organizativamente dispersa. Nesse caso, seria necessário deixar claro o que exatamente se concebe por "grupo", antes de partir para uma discussão sobre "grupo étnico".

20 O resultado dessas mutações sendo apontado, de acordo com a inclinação do observador, ora como exemplo de progresso, evolução social ou de consciência e integração na vida nacional, ora como sinais da degeneração, miscigenação ou sincretismo, que leva à perda da pureza original.

${ }^{21} \mathrm{Na}$ falta dos sinais diacríticos mais evidentes, a solução do órgão repetiu a sua natureza burocrática, estabelecendo um critério fixo, de observação direta e imediata e de fácil apreensão. Quando um representante da Funai visitava uma aldeia do Nordeste em processo de reconhecimento, ele preliminarmente pedia que o grupo demonstrasse que sabia dançar o "Toré" e, a partir da performance, tecia considerações acerca da sua autenticidade étnica, que eram levadas em con- 
ta ao longo do seu processo de reconhecimento. Com isso, quem não possuísse o Toré entre os seus rituais arriscava-se a não ser reconhecido, levando a que, em muitos casos, eles procurassem aprendê-lo com grupos de tronco velho, tornandose uma "expressão obrigatória da indianidade" (A rruti 1996).

\section{Referências bibliográficas}

AHMAD, Aijaz. 1988. “A Retórica da Alteridade de J ameson e a 'A legoria Nacional'". N ovos Estudos CEBRAP, 22:157-181.

ANDERSON, Benedict. 1989. Nação e Consciência Nacional. São Paulo: Ática.

ARRUTI, J osé Maurício Andion. 1995. “M orte e Vida do Nordeste Indígena: A Emergência Étnica como Fenômeno Histórico Regional". Estudos Históricos, 15:57-94.

. 1996. O Reencantamento do Mundo: Trama Histórica e Arranjos Territoriais Pankararu. Dissertação de Mestrado, PPGAS/MN/UFRJ . . 1997. Mocambo de Porto da FoIha: Parecer Histórico-A ntropológico para o Projeto Quilombos Terras de Preto (CETT/M inistério da Cultura convênio n. E132/96-SE). 73ff.

ASSUNÇÃO, Luiz C. 1994. Os Negros do Riacho: Estratégias de Sobrevivência e Identidade Social. Natal: UFRN/ CCHLA.

BAIOCCHI, Mari de N. 1983. Negras de Cedro: Estudo Antropológico de um Bairro Rural de Negros em Goiás. São Paulo: Ática.

BANDEIRA, Maria de Lourdes. 1988. Território N egro em Espaço Branco: Estudo Antropológico de Vila Bela. São Paulo: Brasiliense.

BANTON, Michael. 1979. A Idéia de Raça. Lisboa: Edições 70.
BARRETO FILHO, Hênio T. 1992. Tapebas, Tapebanos e Pernas de Pau: Etnogênese como Processo Social e Luta Simbólica. Dissertação de M estrado, PPGAS/MN/UFRJ .

BARTH, Fredrik. 1969. "Introduction". In: Ethnic Groups and Boundaries. Bergen-Oslo: Universitets Forlaget. pp. 9-38.

BATISTA, Mércia. 1992. De Caboclos da Assunção a Índios Truká. Dissertação de M estrado, PPGAS/M N/UFRJ . BENJ AM IN, Walter. 1987. "Sobre o Conceito de História". In: Walter Benjamin - Obras Escolhidas: Magia e Técnica, Arte e Política. São Paulo: Brasiliense. pp. 222-234.

BOURDIEU, Pierre. 1989. “Le M ort Sainsit le Vif. As Relações entre a História Reificada e a História Incorporada". In: A Economia das Trocas Simbólicas. Rio de J aneiro/Lisboa: Bertrand Brasil/Difel. pp. 75-106.

BRANDÃO, C. R. 1977. Peões, Pretos e Congos: Trabalho e Identidade Étnica em Goiás. Brasília: Ed. da UnB.

CARDOSO DE OLIVEIRA, Roberto. 1976[1971]. Identidade, Etnia e Estrutura Social. São Paulo: Pioneira.

. 1978. Sociologia do Brasil Indígena. Rio de J aneiro: Tempo Brasileiro. CARNEIRO DA CUNHA, M anuela. 1986 [1979]. Antropologia do Brasil: Mito, História, Etnicidade. São Paulo: Brasiliense. 
. 1992. "Política Indigenista no Século XIX". In: Os Povos Indígenas no Brasil. São Paulo: Companhia das Letras. pp. 133-154.

CARVALHO, J osé J . de (org.). 1996. O Quilombo de Rio das Rãs: História, Tradições e Lutas. Salvador: CEAO/ EDUFBA.

CARVAlHo, Maria Rosário. 1984. “A Identidade dos Povos Indígenas do Nordeste". Anuário A ntropológico 82. Brasília: Tempo Brasileiro. pp. 169-187.

COHEN, Abner. 1974. "Introduction: The Lesson of Ethnicity". In: Urban Ethnicity. London: Tavistock (ASA M onographs,12). pp. IX-XXIV.

DANTAS, Beatriz Góes et alii. 1992. “Os Povos Indígenas do Nordeste Brasileiro: Um Esboço Histórico". In: Os Povos Indígenas no Brasil. São Paulo: Companhia das Letras. pp. 431-456.

DANTAS, Beatriz Góes e DALLARI, Dalmo Abreu. 1980. Terra dos Índios Xocó: Estudos e Documentos. São Paulo: Comissão Pró-Índio.

DESPRES, Leo A. 1975. "Towards a Theory of Ethnic Phenomena". In: Ethnicity and Resource Competition in Plural Societies. Paris: Mouton. pp. 187-207.

FORTES, M. e EVANS-PRITCHARD, E. E. 1981[1940]. Sistemas Políticos Africanos. Lisboa: Fundação Calouste Gulbenkian.

FREEDMAN, Maurice. 1986. “Descendência”. Dicionário de Ciências Sociais. Rio de J aneiro: MEC/Fundação Getulio Vargas. pp. 324-325.

GALATY, J ohn G. 1982. “Being M aasai, Being People-of-Cattle: Ethnic Shifters in East Africa". American Ethnologist, 9(1):1-20.

GALLAGHER, J oseph T. 1974. "The Emergence of an African Ethnic Group: The Case of the Ndendeuli". The International J ournal of Amer- ican Historical Studies, 7(1):1-26. GOMES, Flávio dos Santos. 1996. “Em torno dos Bumerangues: Outras Histórias de Mocambos na Amazônia Colonial". Revista USP, 28:40-55.

GRUNEWALD, Rodrigo. 1993. Regime de Índio e Faccionalismo: Os A tikum da Serra do Umã. Dissertação de Mestrado, PPGAS/MN/UFRJ .

GUSMÃO, Neusa M. M. 1979. Campinho da Independência: Um Caso de Proletarização Caiçara. Dissertação de M estrado, PUC/SP.

HOBSBAWM, Eric e RANGER, Terence (orgs.). 1984. “Introdução”. In: A Invenção das Tradições. Rio de J aneiro: Paz e Terra. pp. 9-24.

KEYES, Charles. 1976. "Towards a New Formulation of the Concept of Ethnic Group". Ethnicity, 3(3):202-213.

MARTINS, Silvia. 1994. Os Caminhos da Aldeia: Os Índios Xukuru-Kariri em Diferentes Contextos Situacionais. Dissertação de M estrado, UFPE.

MIRADOR. 1980. Dicionário Brasileiro da Língua Portuguesa. São Paulo: Encyclopédia Britânica do Brasil/ Companhia M elhoramentos de São Paulo.

MonTEIRO, A nita M. Q. 1985. Castainho: Etnografia de um Bairro Rural de Negros. Recife: Fundação J oaquim Nabuco.

MONTEIRO, J ohn. 1994. Negros da Terra. Índios e Bandeirantes na Formação de São Paulo. São Paulo: Companhia das Letras.

OLIVEIRA, Claudia Menezes Paes de. 1951. Singularidade dos Quilombos. Departamento de Ciências Sociais/ UFF. $10 \mathrm{ff}$.

OLIVEIRA FILHO, J oão Pacheco de. 1988. O "Nosso Governo": Os Ticuna e o Regime Tutelar. São Paulo: Marco Zero. . 1993. “'A Viagem da Volta'. Reelaboração Cultural e Horizonte Político dos Povos Indígenas no Nordes- 
te". In: Atlas das Terras Indígenas do Brasil. Rio de J aneiro: Museu Nacional.

PERES, Sidney C. 1992. Arrendamentos de Terras Indígenas: Análises de AIguns M odelos de A ção Indigenista no N ordeste (1910-1960). Dissertação de Mestrado, PPGAS/MN/UFRJ .

PETI - Projeto Estudos sobre Terras Indígenas. 1993. Atlas das Terras Indígenas do Brasil. Rio de J aneiro: Museu Nacional.

QUEIROZ, Renato. 1983. Caipiras Negros no Vale da Ribeira: Um Estudo de Antropologia Econômica. Dissertação de Mestrado, FFLCH/USP.

REIS, J oão J osé. 1996. “Quilombos e Revoltas de Escravos no Brasil". Revista USP, 28:14-39.

RIBEIRO, Darcy. 1978. Os Índios e a Civilização (2a ed.). Petrópolis: Vozes.

SADER, Eder e PAOLI, Maria Célia. 1986. “Sobre 'Classes Populares' no Pensamento Sociológico Brasileiro (Notas de Leitura sobre A contecimentos Recentes)". In: R. Cardoso (org.), A Aventura Antropológica Teoria e Pesquisa. Rio de J aneiro: Paz e Terra.

SAID, Edward W. 1990. Orientalismo: O Oriente como Invenção do Ocidente. São Paulo: Companhia das Letras.

SIDER, Gerald M. 1976. “Lumbre Indian Cultural Nationalism or Ethnogenesis". Dialetical A nthropology, 1(2): 161-172.

SILVA, Dimas S. da. 1994. “Direito Insurgente do Negro no Brasil: Perspectivas e Limites no Direito Oficial". In: S. Donizete Chagas (org.), Lições de Direito Civil Alternativo. São Paulo: Ed. Acadêmica.

SILVA, Orlando S., LUZ, Lídia e HELM, Cecília M. V. (orgs.). 1994. A Perícia Antropológica em Processos J udiciais. Florianópolis: Ed. da UFSC.

SOARES, L. E. 1981. Campesinato, Ideo- logia e Política. Rio de J aneiro: Zahar.

SoUZA, V. F. 1992. As Fronteiras do 'Ser Xucurú': Estratégias e Conflitos de um Grupo Indígena do Nordeste. Dissertação de Mestrado, PPGA/UFPE.

STOLCKE, Verena. 1991. “Sexo Está para

Gênero assim como Raça para Etnicidade?". Estudos Afro-Asiáticos, 20:101-120.

TElles, M. O. da C. (s/d). Produção Camponesa em Lagoa Preta: Etnia e Patronagem. Dissertação de Mestrado, UnB.

VALLE, Carlos Guilherme do. 1993. Terra, Tradição e Etnicidade: Os Tremembé do Ceará. Dissertação de Mestrado, PPGAS/MN/UFRJ .

VOGT, Carlos e FRY, Peter. 1981. “Ditos e Feitos da Falange Africana do Cafundó e da Calunga do Patrocínio (ou como Fazer Falando)". Revista de Antropologia, 26:65-92.

. 1982. “A Descoberta do Cafundó: Alianças e Conflitos no Cenário da Cultura Negra no Brasil". Religião e Sociedade, 8:45-52.

. 1983. “Cuiapar e Cuendar para Conjenga Carunga: A M orte e a M orte no Cafundó". In: J . de S. Martins (org.), A M orte e os M ortos na Sociedade Brasileira. São Paulo: Hucitec. . 1996. Cafundó. A África no Brasil. São Paulo: Companhia das Letras.

VOGT, Carlos, FRY, Peter e GNERRE, Maurizio. 1983. “M afambura e Caxampura: Na Encruzilhada da Identidade". In: L. A. Machado da Silva et alii, M ovimentos Sociais Urbanos, M inorias Étnicas e Outros. Anpocs (Ciências Sociais Hoje, vol. 2).

WEBER, Max. 1991. “Relações Comunitárias eÉtnicas". In: Economia e Sociedade: Fundamentos da Sociologia Compreensiva. Brasília: Editora da UnB. WOLF, Eric. 1988. "Inventing Society". American Ethnologist, 15(4):752-761. 
Resumo

M otivado pelos efeitos políticos decorrentes da adoção do termo "remanescentes" na legislação relativa a grupos indígenas e negros rurais, assim como baseado em literatura histórica e etnográfica, este artigo discute os limites analíticos e teóricos da polarização, corrente na literatura de ciências sociais no Brasil, entre os classificadores "raça" e "etnia". A nalisa a convergência temática e conceitual de estudos recentes baseados nesses dois classificadores e relativiza a consistência dessa repartição em várias situações sociais documentadas, para propor a idéia de "plasticidade identitária". Esta idéia serve de base a uma reflexão sobre a estreita relação entre produção científica, criação jurídica e ação política, levando à sugestão de se pensar as situações vividas por aquelas comunidades chamadas "remanescentes" em termos de emergência étnica e invenção cultural.

\section{Abstract}

Supported by a reading of the historical and ethnographical literature, this article addresses the political consequences of the adoption of remnants [remanescentes] as a legislative term describing indigenous groups and rural AfroBrazilian populations, and discusses the analytic and theoretical limits of the current polarization of "race" and "ethnic group" in Brazilian social sciences. Proposing the concept of "plastic identity", it analyzes the thematic and conceptual convergence of recent studies based on these two classifiers and questions the stability of their separation through recourse to a number of documented social situations. This concept allows a reflection on the close relationship between scientific production, juridical training and political action. $\mathrm{Fi}$ nally, a proposal is made to rethink the lifeworlds of communities designated "remnants" in terms of ethnic emergence and cultural invention. 